НАУКОВИЙ ВІСНИК

Sientific messenger of Liviv National University of

-

(b)

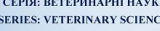

Том 22 № 100

2020
Науковий вісник Дьвівського національного університету ветеринарної медицини та біотехнологій імені С.3. Гжицького. Серія: Ветеринарні науки

\author{
Scientific Messenger of Lviv National University
} of Veterinary Medicine and Biotechnologies. Series: Veterinary sciences

UDC 619:576.32/36:615.363:616.15:636

\title{
Peculiarities of influence of the preparation moxistop (tablet) on biochemical indicators of blood of small pets
}

\author{
S. A. Sapko \\ Limit liability company "Scientific and production enterprise of "Suzirya”, Kharkov, Ukraine
}

Article info

Received 08.10.2020

Received in revised form 09.11 .2020

Accepted 10.11.2020

Limit liability company "Scientific and production enterprise of "Suzirya", Zernovaya Str., 4 Kharkov, 61105, Ukraine. Tel.: +38-099-458-90-03 E-mail:sapko.s@priroda.ua
Sapko, S. A. (2020). Peculiarities of influence of the preparation moxistop (tablet) on biochemical indicators of blood of small pets. Scientific Messenger of Lviv National University of Veterinary Medicine and Biotechnologies. Series: Veterinary sciences, 22(100), 78-83. doi: $10.32718 /$ nvlvet10014

This article describes studies of the veterinary anthelmintic preparation Moxistop (tablet) for dogs and cats. The preparation Moxistop (tablet) has a wide range of action, thanks to its unique formula moxidectin + praziquantel fights 13 types of parasites, including microfilariae (Dirofilaria repens, Dirofilaria immitis), it is used for prophylactic and therapeutic purposes in nematodes and cestodes. Analysis of the dynamics of clinical indicators of the blood of cats showed that the animals of the first and second groups, all indicators were normal. Eosinophils before deworming in animals of the first group were increased and amounted to $(8.2 \pm 0.93) \%$ (normal (2-6) \%), and after deworming to the 14 th day decreased to $(4.7 \pm 0.51) \%$; in cats of the second group decreased from $(9.7 \pm 1.14) \%$ to $(5.5 \pm 0.49) \%$. According to the study, it was found that in the studied dogs of one group after the use of the preparation "Moxistop" tablet blood hemoglobin tended to increase relative to normal, namely by $28 \%$, and in group V within normal limits. The content of erythrocytes, leukocytes, eosinophils, lymphocytes and ESR - within normal limits. It should be noted that before deworming in animals of the fourth group, blood parameters, namely eosinophils, were at the upper limit of normal and were $(7.9 \pm 2.63) \%$ (normal (2-8) \%), and after deworming to 14 on the th day decreased to $(5.4 \pm 1.44) \%$; in dogs of the fifth group decreased from $(7.1 \pm 1) \%$ to $(4 \pm 1) \%$, in animals of the control group was more than $7 \%$, which is the upper limit of normal. According to the results of the tests, it was found high efficiency of the preparation "Moxistop" ("Moxistop mini", "Moxistop copper", "Moxistop maxi") in the infestation of Dipylidium caninum, Toxascaris leonina and Dirofilaria immitis in dogs and cats of different ages.

Key words: small pets, deworming, anthelmintics, biochemical analysis of blood, Moxistop (tablet).

\section{Особливості впливу препарату моксістоп (таблетка) на біохімічні показники крові дрібних домашніх тварин}

\author{
С. А. Сапко
}

Товариство з обмеженою відповідальністю “Науково виробниче підприємство “Сузір’я”, м. Харків, Украӥна

\footnotetext{
У представленій статті описані дослідження щодо застосування ветеринарного антигельмінтного препарату Моксістоп (таблетка) з метою профілактики гельмінтозів у собак та котів різних вікових груп. Данні дослідження актуальні в зв'язку тим, що на ринку присутній досить великий асортимент антигельмінтних препаратів, Моксістоп (таблетка) з вхідними в його склад речовинами оберігає організм тварини від великого спектра гельмінтів, в тому числі і від дирофілярій. Профілактика гельмінтозів - важливий протиепізоотичний захід, який проводиться не рідше одного разу на квартал. Застосований препарат Моксістоп (таблетка) має широкий спектр дї, завдяки своїй унікальній формулі моксідектин + празиквантел бореться з 13-ма видами паразитів, включаючи мікрофілярії (Dirofilaria repens, Dirofilaria immitis), його застосовують з профілактичною і лікувальною метою при нематодозах і цестодозах. Аналіз динаміки клінічних показників крові котів показав, що у тварин першої та другої груп всі показники знаходилися в нормі. Еозинофіли перед дегельмінтизацією у тварин першої групи були підвищені $i$ становили
} 
$(8,2 \pm 0,93) \%$ (при нормі (2-6) \%), а після дегельмінтизачії до 14-го дня знизилися до $(4,7 \pm 0,51) \%$; у котів другої групи знизилися з $(9,7 \pm 1,14) \%$ до $(5,5 \pm 0,49) \%$. За результатом дослідження виявлено, щзо у досліджуваних собак однієї групи після застосування препарату “Моксістоп” таблетка показник гемоглобіну крові мав тенденцію до підвищення по відношенню до норми, а саме на $28 \%$, а в V групі в межах норми. Зміст еритроцитів, лейкочитів, еозинофілів, лімфоцитів і ШОЕ - в межах норми. Слід зазначити що перед дегельмінтизацією у тварин четвертої групи показники крові, а саме еозинофіли, були на верхній межі норми і складали (7,9 $\pm 2,63) \%$ (при нормі (2-8) \%), а після дегельмінтизації до 14-го дня знизилися до $(5,4 \pm 1,44) \%$; у собак п'ятої групи знизилися з $(7,1 \pm 1) \%$ до (4 \pm 1$) \%$, у тварин контрольної групи становили понад 7 \%, що є верхньою межею норми. Відповідно до результатів проведених випробувань, встановлена, висока ефективність застосування препарату "Моксістоп” ("Моксістоп міні”, "Моксістоп міді", "Моксістоп максі") при інвазуванні Dipylidium caninum, Toxascaris leonina ma Dirofilaria immitis y coбак та котів різних вікових груп.

Ключові слова: дрібні домашні тварини, дегельмінтизація, антигельмінтики, біохімічний аналіз крови, Моксістоп (таблетка).

\section{Вступ}

Гельмінтози м’ясоїдних досить широко поширені в усьому світі, в тому числі і на території нашої країни. Поширення інвазії відбувається 3 різних причин, однією $з$ яких є проведення дегельмінтизації тварин без урахування біологічного циклу розвитку паразитів, або зовсім відмова від обробки (Pryima, 2013; Bakhur, 2014; Said et al., 2020). Вивчення різних аспектів гельмінтозів заслуговує пильної уваги не тільки з огляду визначення шкоди для тварин, а й з урахуванням ймовірності зараження людини (Volychev, 2003; Dubyna \& Yatusevych, 2005).

Людина давно оцінила корисні якості собаки i приручила іiі раніше за інших тварин. 3 давніх часів собак застосовували у військовій справі для вартової служби або для безпосереднього нападу на супротивника, полювання та інше (Farytov et al., 2009). Тобто тварина повинна бути постійно готова до випробувань, бути здоровою. Запорука здорової тварини насамперед профілактика. До профілактики відноситься і щоквартальна дегельмінтизація, яка дозволяє зберегти здоров'я тварини і підвищити засвоюваність раціонів харчування (Soldatov \& Karmalyev, 2016).

Не менше за захворюваність собак, інтерес представляє і епізоотична ситуація з гельмінтозів у котів, оскільки ці тварини утримуються майже в кожній родині i, як правило, знаходяться в більш тісному контакті з людиною, ніж собаки (Bortsova et al., 2004).

Дегельмінтизація як лікувальна так і профілактична повинна бути ефективна, тож необхідно застосовувати відповідні препарати. 3 даною метою застосовували тваринам (котам та собакам) препарат Моксістоп (таблетка). Даний препарат нами був обраний у зв'язку $з$ невисокою ціною, а також комплексною дією проти гельмінтів, в тому числі й дирофілярій. У своєму складі таблетка містить моксідектин + празиквантел.

Мета дослідження: визначити вплив ветеринарного препарату Моксістоп (таблетка) на біохімічні показники крові собак і кішок.

Завдання дослідження:

- визначити фонові показники крові собак та котів;

- виявити вплив антигельмінтного препарату Моксістоп на біохімічні показники крові.

\section{Матеріал і методи досліджень}

Дослідження проводили на базі приватної ветеринарної клініки м. Харків. Було відібрано 27 котів (у віці від 7-ми місяців до 6-ти років) і 30 собак (1-2річного віку вагою 18-20 кг, 3-5 тижневого віку вагою 1-1,5 кг), що належать власникам, які проживають в різних районах м. Харкова.

Тварини були спонтанно інвазовані гельмінтами. Групи формували $з$ тварин, в анамнезі яких були наступні ознаки: змінений апетит (відсутній, підвищений), тьмяна шерсть, свербіж, діарея, що змінюються закрепами, запалення в області ануса, пересування тварин в сидячому положенні. У декількох собак у крові були виявлені мікрофілярії Dirofilaria immitis.

При огляді тварин проводили такі маніпуляції: термометрію, зважування тварин, оцінювали колір слизових оболонок, звертали увагу на наявність розчухи на тілі тварин, наявність ектопаразитів (бліх $\mathrm{i}$ волосоїдів) або на фази їх розвитку. Фекалії тварин збирали не пізніше 5-ти хвилин після дефекації за допомогою дерев'яного шпателя і поміщали в герметичні одноразові контейнери об'ємом 50 мл. Матеріал доставляють у ветеринарну клініку не пізніше 6-ти годин $з$ моменту збору. Копроовоскопічні дослідження проводили за методом Фюллеборна на виявлення яєць гельмінтів у фекаліях тварин з подальшим диференціюванням. Дослідження фекальних мас проводили в день дегельмінтизації (перед проведенням дегельмінтизації). Повторне дослідження було на 14-й день після дегельмінтизації. Після підтвердження діагнозу сформували групи зі спонтанно заражених тварин по мірі надходження їх в клініку.

Перша група була сформована 3 10-ти котів віком від 7-ми місяців до 1 року, у яких при дефекації виділялося від 1-го до 5-ти члеників дипілідіума. Всім котам призначали препарат "Моксістоп міні" з розрахунку 1 таблетка на 4 кг маси тварини одноразово. Препарат задавали тваринам перорально, примусово на корінь язика на прийомі у ветеринарній клініці. Впродовж години вели спостереження в умовах стаціонару, оцінюючи їх загальний стан, а потім рекомендували власникам спостерігати за тваринами в домашніх умовах.

Другу групу формували 3 кішок в кількості 10-ти голів у віці від 1 року до 5-ти років, у яких виділялося 3 фекаліями більше 5-ти члеників діпілідіума. Тваринам цієї групи препарат “Моксістоп міді” призначали з розрахунку 1 таблетка на 10 кг маси тварини дворазово з інтервалом в 14 діб.

Третя група (контрольна котів) була сформована 3 7-ми тварин, у яких 3 фекаліями виділялося до 5-ти члеників огіркового ціп'яка. Тваринам препарат “Моксістоп” не призначали. 
Четверта група - 5 собак у віці 3-5 тижнів. Задавали препарат “Моксістоп міні” 1/2 таблетки перорально одноразово на 1-2 кг ваги тварини.

До п’ятої групи потрапили 3 собаки 1-2-х річного віку, яким задавали “Моксістоп Максі” в дозі 1 таблетка на 10-20 кг ваги тварини дворазово з інтервалом в 14 діб.

Шоста група тварин (контрольна група собак) в кількості 5, не отримувала препарат.

Для визначення фізіологічного статусу тварин до i після дегельмінтизації брали кров для клінічного i біохімічного аналізу. Відбір крові проводили до ранкової годівлі і визначали показники загального та біохімічного аналізів крові. До застосування препарату проводили відбір крові для встановлення показників крові, повторне дослідження - через 14 діб після застосування препарату Моксістоп. Препарат давали тваринам згідно з інструкції. Лабораторні дослідження проводили в умовах приватної клініко-біохімічної лабораторії загальноприйнятими методами в напівавтоматичному аналізаторі.

Всі коти (27 голів) та собаки (30 голів) були оброблені краплями спот-он “Інсектостоп”, що містять в якості діючої речовини фіпроніл. Приміщення, в яких містилися тварини, а також предмети догляду за ними були оброблені препаратом спрей “Інсектостоп”. Обробляли стіни на висоту не менше 0,5 м, поверхня підлоги, щілини за плінтусами, килими і килимки біля вхідних дверей.

Статистична обробка отриманих результатів за допомогою офісного програмного комплексу "Microsoft Office" із застосуванням програми "Excel". Різницю вважали достовірною за критерієм Стьюдента та позначали знаком: * - при $\mathrm{P}<0,05$; ** - при $\mathrm{P}<0,01 ; * * *$ - при $\mathrm{P}<0,001$.

\section{Результати та їх обговорення}

При проведені копрологічного дослідження в фекаліях у всіх 27 котів були виявлені членики розміром до 1 см в довжину і (2-3) мм в ширину, за формою нагадують насіннячко огірка, мають білий колір. При мікроскопічному перегляді після просвітління в них виявили численні округло-овальні утворення світлокоричневого кольору (кокони), що містять по (5-7) яєць цестодного типу. На підставі морфологічних ознак визначена належність цестоди - Dipylidium caninum.

У 10-ти кішок (1-а група тварин) встановили виділення члеників в кількості від 1-го до 5-ти при акті дефекації і наявність (1-2) коконів в полі зору при перегляді у мікроскоп, містять (3-4) яєць цестодного типу (х40 при флотаційному дослідженні).

В результаті одноразового застосування препарату “Моксістоп” встановили, що на (4-6) добу після задавання препарату діарея у всіх тварин першої групи припинилася, фекалії стали оформлені, однорідної консистенції, не мали додаткових включень. Слизові оболонки набули рожевий відтінок.

При проведенні копрологічних досліджень через 14 діб після дегельмінтизації членики D. caninum, а також кокони, що містять яйця цестодного типу, у тварин цієї групи не були виявлені.

Тваринам другої групи на 14-у добу повторно дали препарат.

Після другої дегельмінтизації препаратом "Моксістоп" через 14 діб в фекаліях всіх тварин цієї групи не були виявлені членики і яйця $D$. caninum. Фекалії були оформлені, апетит тварин був помірний, розчісування в області ануса не спостерігалося.

Результати клінічного аналізу крові на 14-у добу після дегельмінтизації препаратом “Моксістоп” показали, що у кішок з першої і другої груп всі показники знаходилися в нормі. Еозинофіли - маркери паразитарних інвазій, перед дегельмінтизацією у тварин першої групи були підвищені і становили $(8,2 \pm 0,93) \%$ (при нормі (2-6) \%), а після дегельмінтизації до 14-го дня знизилися до $(4,7 \pm 0,51) \%$; у кішок другої групи знизилися з $(9,7 \pm 1,14) \%$ до $(5,5 \pm 0,49) \%$, у тварин контрольної групи становили понад 7 \% по відношенню до норми. Застосування препарату не зробило негативного впливу на гемопоез у кішок. Тваринам контрольної групи після випробування провели дегельмінтизацію дворазово.

У 5-ти собак четвертої групи (цуценят) встановлено виділення яєць аскаридного типу. В полі зору при перегляді в мікроскопі виявили (1-3) яйця Toxascaris leonina (х40 при флотаційному дослідженні). В peзультаті одноразового застосування препарату "Моксістоп” встановили, що на (4-5) добу після дачі препарату діарея у всіх тварин цієї групи припинилася, фекалії стали оформлені, однорідної консистенції. До початку задавання препарату у всіх тварини спостерігались здуття животу або “пузатий” вигляд, який на (2-3) добу зник. При проведенні копрологічних досліджень через 14 діб після дегельмінтизації яєць Toxascaris leonina у тварин цієї групи не були виявлеHi.

Тварини п’ятої групи мали у фекаліях яйця Toxascaris leonina та були виявлені мікрофілярії Dirofilaria immitis у різній кількості (від 1 до 3 у полі зору). За результатом одноразового задавання препарату покращився загальний стан тварин (фекалії стали оформлені, однорідної консистенції) та кількість мікрофілярій зменшилась від 0 до 2 у полі зору. Тваринам п'ятої групи на 14-ту добу повторно дали препарат. Після другої дегельмінтизації препаратом "Моксістоп” через 14 діб в фекаліях всіх тварин цієї групи не були виявлені яйця Toxascaris leonina та були виявлені мікрофілярії Dirofilaria immitis.

Тварини шостої групи (контрольної) у фекаліях не мали яєць гельмінтів, але були виявлені мікрофілярії Dirofilaria immitis у різній кількості (від 0 до 2 у полі зору). По завершенню випробування їм дворазово задали препарат.

За результатом дослідження виявлено, що у досліджуваних тварин після застосування препарату "Моксістоп” показники крові підвищено: вміст гемоглобіну по відношенню до норми на $28 \%$ в IV групі, а в $\mathrm{V}$ групі в межах норми. Зміст еритроцитів, лейкоцитів, еозинофілів, лімфоцитів і ШОЕ - в межах норми. Слід зазначити що перед дегельмінтизацією у тварин 
четвертої групи показники крові були на верхній межі норми і складали $(7,9 \pm 2,63) \%$ (при нормі (2-8) \%), а після дегельмінтизації до 14-го дня знизилися до $(5,4 \pm 1,44) \%$; у собак п'ятої групи знизилися 3 $(7,1 \pm 1) \%$ до $(4 \pm 1) \%$, у тварин контрольної групи становили понад 7 \%, що є верхньою межею норми. Застосування препарату не зробило негативного впливу на гемопоез у собак. Результати клінічного аналізу крові тварин представлені в таблиці 1.

Таблиця 1

Результати клінічного аналізу крові тварин на 1-й і 14-й день досвіду

\begin{tabular}{|c|c|c|c|}
\hline Показник & 1 доба & 14 доба & Референтне значення \\
\hline \multicolumn{4}{|c|}{ Група I (одноразове використання препарату “Моксістоп” котам) } \\
\hline ШОЕ, мм/ч & $11,1 \pm 1,59$ & $9,9 \pm 1,21$ & $0-13$ \\
\hline Лейкоцити, Г/л & $14,5 \pm 2,71$ & $13,8 \pm 2,69$ & $8-18$ \\
\hline Еритроцити, Т/л & $7,1 \pm 0,87$ & $8,8 \pm 1,09$ & $6,6-9,4$ \\
\hline Гемоглобін, г\% & $100,5 \pm 3,87$ & $104,7 \pm 3,96$ & $100-140$ \\
\hline Еозинофіли, \% & $8,2 \pm 0,93 \uparrow$ & $4,7 \pm 0,51$ & $2-6$ \\
\hline \multicolumn{4}{|c|}{ Група II (дворазове використання “Моксістоп” котам) } \\
\hline ШОЕ, мм/ч & $11,8 \pm 1,53$ & $10,0 \pm 1,58$ & $0-13$ \\
\hline Лейкоцити, Г/л & $15,4 \pm 1,89$ & $12,8 \pm 1,74$ & $8-18$ \\
\hline Еритроцити, Т/л & $6,4 \pm 0,87$ & $6,9 \pm 0,95$ & $6,6-9,4$ \\
\hline Гемоглобін, г\% & $109,2 \pm 2,61$ & $116,9 \pm 2,75$ & $100-140$ \\
\hline Еозинофіли, \% & $9,7 \pm 1,14 \uparrow$ & $5,5 \pm 0,49$ & $2-6$ \\
\hline \multicolumn{4}{|c|}{ Група III (контрольна котів) } \\
\hline ШОЕ, мм/ч & $12,5 \pm 1,27$ & $12,3 \pm 1,15$ & $0-13$ \\
\hline Лейкоцити, Г/л & $14,8 \pm 1,84$ & $14,9 \pm 1,86$ & $8-18$ \\
\hline Еритроцити, Т/л & $6,05 \pm 0,22$ & $6,14 \pm 0,24$ & $6,6-9,4$ \\
\hline Гемоглобін, г\% & $99,5 \pm 2,58$ & $100 \pm 2,97$ & $100-140$ \\
\hline Еозинофіли, \% & $7,8 \pm 0,49 \uparrow$ & $7,7 \pm 0,42 \uparrow$ & $2-6$ \\
\hline \multicolumn{4}{|c|}{ Група IV (одноразове використання препарату “Моксістоп” собакам) } \\
\hline ШОЕ, мм/ч & $9,8 \pm 3,19$ & $7,8 \pm 0,27$ & $0-13$ \\
\hline Лейкоцити, Г/л & $7,0 \pm 0,77$ & $5,32 \pm 1,24$ & $5,5-19,5$ \\
\hline Еритроцити, Т/л & $6,28 \pm 1,33$ & $5,64 \pm 1,88$ & $5,8-10,7$ \\
\hline Гемоглобін, г\% & $138,2 \pm 14,40$ & $167,8 \pm 10,08 \uparrow$ & $90-150$ \\
\hline Еозинофіли, \% & $7,9 \pm 2,63$ & $5,4 \pm 1,44$ & $2-8$ \\
\hline \multicolumn{4}{|c|}{ Група V (дворазове використання “Моксістоп” собакам) } \\
\hline ШОЕ, мм/ч & $6,33 \pm 1,44$ & $4,33 \pm 1,39^{*}$ & $0-13$ \\
\hline Лейкоцити, Г/л & $12,6 \pm 2,36$ & $10,2 \pm 1,67 *$ & $5,5-19,5$ \\
\hline Еритроцити, Т/л & $6,77 \pm 0,81$ & $8,0 \pm 1,66$ & $5,8-10,7$ \\
\hline Гемоглобін, г\% & $97,67 \pm 6,66$ & $122,67 \pm 12,06$ & $90-150$ \\
\hline Еозинофіли, \% & $7 \pm 1$ & $4 \pm 1$ & $2-8$ \\
\hline \multicolumn{4}{|c|}{ Група VI (контрольна собак) } \\
\hline ШОЕ, мм/ч & $10,4 \pm 1,14$ & $10,8 \pm 1,1$ & $0-13$ \\
\hline Лейкоцити, Г/л & $15,58 \pm 1,78$ & $16,06 \pm 1,78$ & $5,5-19,5$ \\
\hline Еритроцити, Т/л & $7,1 \pm 0,81$ & $7,42 \pm 0,64$ & $5,8-10,7$ \\
\hline Гемоглобін, г\% & $98,4 \pm 4,93$ & $98,2 \pm 2,48$ & $90-150$ \\
\hline Еозинофіли, \% & $7,6 \pm 1,14$ & $7,2 \pm 0,84$ & $2-8$ \\
\hline
\end{tabular}

Після дегельмінтизації у тварин першої і другої груп була відзначена тенденція до збільшення загального білка в сироватці крові, зниження рівня сечовини. У контрольній групі показники загального білка залишалися нижче норми, а рівень АСТ, лужної фосфатази був вище допустимих показників. Зміни біохімічних показників крові котів, зафіксовані на 1-у та 14-у добу досліду, представлені дані в таблиці 2.

За результатом дослідження біохімічних показників крові у тварин IV групи виявлено, що показник сечовини перевищує норму на $11 \%$, лужна фосфотаза на початку випробування перевищує норму на $15 \%$, вміст загального білку, білірубіну, АЛТ, АСТ, креатиніну - в межах норми. Що до тварин V групи то показник сечовини був в нормі (на верхній межі), лужна фосфотаза на початку випробування перевищує норму на $17 \%$.

В таблиці 3 відображено динаміку біохімічних показників крові собак.

За всіма тваринами вели спостереження впродовж 2-х місяців. У всіх котів першої і другої груп виділення члеників $D$. caninum не відзначалося. У котів третьої групи стан змінився незначно. Після обробки інсектицидними препаратами свербіж значно зменшився, проте зберігалася діарея, яка через 2 доби змінювалася закрепом. У фекаліях при візуальному огляді знаходили членики D. caninum. 
Таблиця 2

Біохімічні показники крові котів на 1-у та 14-у добу дослідження (групи I - III)

\begin{tabular}{|c|c|c|c|c|c|c|c|}
\hline \multirow[t]{2}{*}{ Показник } & \multirow[t]{2}{*}{ норма } & \multicolumn{2}{|c|}{$\begin{array}{c}\text { Група I (одноразове } \\
\text { застосування препарату } \\
\text { "Моксістоп") }\end{array}$} & \multicolumn{2}{|c|}{$\begin{array}{c}\text { Група II (дворазове } \\
\text { застосування препарату } \\
\text { "Моксістоп") }\end{array}$} & \multicolumn{2}{|c|}{ Група III (контрольна) } \\
\hline & & 1 доба & 14 доба & 1 доба & 14 доба & 1 доба & 14 доба \\
\hline Загальний протеїн, г/л & $58-82$ & $59,1 \pm 2,26$ & $66,8 \pm$ & $63,6 \pm 2,81$ & $69,9 \pm 2,76$ & $57,8 \pm 3,79$ & $56,8 \pm$ \\
\hline Сечовина, ммоль/л & $4,0-8,5$ & $7,1 \pm 0,27$ & $6,43 \pm$ & $6,9 \pm 0,09$ &, 09 & $6,2 \pm 1,27$ & 1,27 \\
\hline Креатинін, ммоль/л & $45-155$ & $119 \pm 4,09$ & $120 \pm 4,18$ & $118,5 \pm 3,92$ & $117,7 \pm 3,76$ & $140,8 \pm 4,24$ & 141,8 \\
\hline Білірубін, мкмоль/л & $0,6-5,0$ & $1,06 \pm 0,01$ & $1,03 \pm 0,01$ & $3,7 \pm 0,47$ & $4,5 \pm 0,05$ & $3,9 \pm 0,74$ & $3,87 \pm 0,67$ \\
\hline АЛТ, Од/л & $8-50$ & $34,7 \pm 1,68$ & $32,9 \pm 1,29$ & $41,4 \pm 1,38$ & $42 \pm 1,43$ & $48,3 \pm 2,29$ & $49,6 \pm 2,68$ \\
\hline АСТ, Од/л & $8-50$ & $36 \pm 1,83$ & $35,8 \pm 1,76$ & $46 \pm 1,69$ & $45,2 \pm 1,67$ & $54,6 \pm 2,76 \uparrow$ & $55,4 \pm 2,81 \uparrow$ \\
\hline Лужна фосфотаза, Од/л & $10-50$ & $57,1 \pm 2,05 \uparrow$ & $48,8 \pm 2,17$ & $59,6 \pm 1,83 \uparrow$ & $47,1 \pm 1,57$ & $55,8 \pm 2,97 \uparrow$ & $57,4 \pm 3,14 \uparrow$ \\
\hline Амілаза, Од/л & до 1500 & $840,5 \pm 6,75$ & $845 \pm 6,89$ & $924 \pm 6,24$ & $896,9 \pm 5,85$ & $910,4 \pm 7,09$ & $933,4 \pm 7,61$ \\
\hline
\end{tabular}

Таблиця 3

Біохімічні показники крові собак на 1-у та 14-у добу дослідження (групи IV - VI)

\begin{tabular}{|c|c|c|c|c|c|c|c|}
\hline \multirow[t]{2}{*}{ Показники } & \multirow[t]{2}{*}{ норма } & \multicolumn{2}{|c|}{$\begin{array}{c}\text { Група IV (одноразове } \\
\text { застосування препарату } \\
\text { "Моксістоп") }\end{array}$} & \multicolumn{2}{|c|}{$\begin{array}{c}\text { Група V (дворазове } \\
\text { застосування препарату } \\
\text { "Моксістоп") }\end{array}$} & \multicolumn{2}{|c|}{ Група VI (контрольна) } \\
\hline & & 1 доба & 14 доба & 1 доба & 14 доба & 1 доба & 14 доба \\
\hline Загальний протеїн, г/л & $57,5-79,6$ & $59,12 \pm 3,23$ & $65,66 \pm 2,09$ & $63,33 \pm 4,98$ & $64,9 \pm 5,37$ & $65,22 \pm 8,03$ & $66,52 \pm 6,42$ \\
\hline Сечовина, м! & $2,0-8,0$ & $8,88 \pm 1,40 \uparrow$ & $7,32 \pm$ & $7,19 \pm 0,49$ & 6,29 & $86 \pm 1,06$ & 01 \\
\hline Креатинін, ммоль/л & $61,8-159,1$ & $95,98 \pm 6,09$ & $88,2 \pm 4,61$ & $108,03 \pm 11,9$ & $106,33 \pm 13,46$ & $86,9 \pm 13,01$ & $84,68 \pm 23,48$ \\
\hline Білірубін, мкмоль/л & $0-6,8$ & $4,3 \pm 0,84$ & $4 \pm 0$ & $4,66 \pm 1,01$ & $3,82 \pm 0,7$ & $3,9 \pm 0,91$ & $3,88 \pm 0,57$ \\
\hline АЛТ, Од/л & $30-100$ & $46,3 \pm 4,62$ & $62,28 \pm 23,03$ & $45,07 \pm 8,45$ & $56,06 \pm 13,44$ & $60,78 \pm 10,50$ & $62,8 \pm 11,68$ \\
\hline АСТ, Од/л & $12-56$ & $41,38 \pm 1,91$ & $52,84 \pm 5,04$ & $31,87 \pm 6,63$ & $42,5 \pm 4,99$ & $38,18 \pm 10,27$ & $40,46 \pm 9,99$ \\
\hline $\begin{array}{l}\text { Лужна } \quad \text { фосфотаза } \\
\text { Од/л }\end{array}$ & $10-80$ & $92,1 \pm 8,04$ & $79,84 \pm 9,01$ & $94,2 \pm 5,96$ & $72,5 \pm 8,29$ & $78,74 \pm 9,03$ & $79,52 \pm 10,53$ \\
\hline Амілаза, Од/л & $400-1100$ & $946 \pm 43,90$ & $688,8 \pm 4,38$ & $787,3 \pm 108,9$ & $728,7 \pm 72,18$ & $784,92 \pm 115,9$ & $726,02 \pm 113,1$ \\
\hline
\end{tabular}

У всіх собак четвертої та п’ятої груп виділення яєць Toxascaris leonina не спостерігалось. Щодо циркуляції у кров'яному руслі мікрофілярії Dirofilaria immitis залишалась на тому ж рівні (від 0 до 2 у полі зору). Після завершення випробування тваринам контрольних груп провели дворазове задавання препарату відповідно до інструкції.

Так за результатом динаміки показників крові, клінічним станом тварин, виявленими збудниками та результатом застосування препарату "Моксістоп" зроблені наступні висновки. Зміни щодо підвищення показнику гемоглобіну у всіх групах (від 4 до 21,5 \%) після проведеної обробки може бути обумовлено знищенням ендопаразитів та як наслідок покращення засвоюваності поживних речовин з раціону. Такі данні прослідковуються і при проведенні дослідження впливу препаратів для дегельмінтизації у інших тварин (Bakhur, 2012; Sheliakyn \& Cheskydova, 2016).

В крові тварин впродовж досліду встановлено зниження показника вмісту еозинофілів у всіх тварин, які отримували препарат, в середньому на $75 \%$ в порівнянні з початковими результатами, що вказує на усунення алергічних компонентів, пов'язаних зі звільненням тварин від паразитів (Kanapelko \& Petrova, 2017).

За результатом проведеної дегельмінтизації препаратом "Моксістоп" собак та котів встановлено позитивний вплив на динаміку гематологічних показників.
Представлені в таблиці 2 та 3 данні вказують на те що звільнення тварин від паразитів впливає на їх біохімічний статус. Так в групах I - II та IV - V встановлено поступове збільшення концентрації загального білку (у котів від 9,9 до $13 \%$, у собак від 2,5 до $11 \%$ ) від початкового рівню. Встановлена тенденція щодо зниження показника лужної фосфотази (у котів від 12, до $17 \%$, у собак від 17 до 26,6 \%), який є маркерним ферментом холестаза. Аналогічна тенденція спостерігалась по відношенню до сечовини: зниження у тварин (котів та собак) від 10 до $13 \%$ від початкового рівню. Отримані нами данні простежуються і в інших випробуваннях (Ybyshov et al., 2017; Havrylova et al., 2017).

Отримані нами результати щодо ефективності та впливу на біохімічні та клінічні показники крові, мають аналогічну динаміку 3 випробуваннями інших науковців, які використовували комбінацію діючих речовин - празіквантел та моксидектин (Arysov et al., 2016; Ybyshov et al., 2017; Havrylova et al., 2017; Kanapelko \& Petrova, 2017).

\section{Висновки}

Відповідно до результатів проведених випробувань, встановлена, висока ефективність застосування препарату "Моксістоп” (“Моксістоп міні”, "Моксістоп міді", “Моксістоп максі") при інвазуванні Dipylidium caninum, Toxascaris leonina та Dirofilaria immitis у собак та котів різних вікових груп. 
Встановлено, що одно- та двократне застосування препарату не має небажаної реакції у тварин, тобто не впливає негативно на гемопоез, не має гепато- та нефротоксичності.

\section{References}

Arysov, M. V., Smyrnova, E. S., Arysova, H. B., Stepanov, V. A., \& Poselov, D. S. (2016). Izuchenie perenosimosti i effektivnosti novoho kompleksnoho preparata Helmyntal tabletky na osnove moksydektyna i prazykvantela [Study of the tolerance and efficacy of the new complex drug Helmintal tablets based on moxidectin and praziquantel]. Russian parasitological journal, 3(37), 403-408 (in Russian).

Bakhur, T. I. (2012). Zminy hematolohichnykh pokaznykiv u bilykh myshei za eksperymentalnoho vistseralnoho toksokarozu ta riznykh metodiv yoho terapii [Changes in hematological indicators in large targets for experimental visceral toxocariasis and other methods of yogo therapy]. Visnyk ZHNAEU, 3(1), 15-19 (in Ukrainian).

Bakhur, T. I. (2014). Toksokaroz sobak i kotiv (poshyrennia, patohenez, zakhody borotby) [Toxocariasis of dogs and cats (spread, pathogenesis, control measures)] (Extended abstract of $\mathrm{PhD}$ dissertation). Natsionalnoy universytet bioresursiv i pryrodokorystuvannia Ukrainy, Kyiv, Ukraina (in Ukrainian).

Bortsova, M. S., Plotnykova, Y. V., \& Zubareva, Y. M. (2004). Rol horodskykh koshek $\mathrm{v}$ epidemiolohii y epyzootolohyy helmyntozov [The role of urban cats in the epidemiology and epizootology of helminthiasis]. Modern problems of epizootology: materials of the International scientific. conf. Novosibirsk, 339-342 (in Russian).

Dubyna, Y. N., \& Yatusevych, A. Y. (2005). Sobaky y koshky kak ystochnyk helmyntozov, opasnykh dlia cheloveka [Dogs and cats as a source of helminthiasis, dangerous to humans]. Epizootology, immunobiology, pharmacology, sanitation, 4, 17-21 (in Russian).

Farytov, T. A., Khazyakhmetov, F. S., \& Platonov, E. A. (2009). Prakticheskoe sobakovodstvo: ucheb. posobye dlia studentov, obuchaiushchykhsia po spets. "Kynolohyia" [Practical dog breeding: textbook. manual for students studying for special. "Cynology"] Ufa, Russia: Bashkir State Agrarian University (in Russian).

Havrylova, N. A., Belova, L. M., \& Kanapelko, E. N. (2017). Otsenka effektyvnosty prymenenyia preparata "Helmymaks" pry dypylydyoze koshek. [Evaluation of the effectiveness of the drug "Helmimax" in cats with dipyldiosis]. Topical issues of veterinary biology, 4(36), 25-30 (in Russian).

Kanapelko, E. N., \& Petrova, O. V. (2017) Yzuchenye perenosymosty kombynatsyy moksydektyna y prazykvantela na kotiatakh y shchenkakh [Study of the tolerance of the combination of moxidectin and praziquantel in kittens and puppies]. Regulatory issues in veterinary medicine, 2, 76-79. URL: https://apicenna.ru/news/izuchenie-perenosimostikombinacii-moksidektina-i-prazikvantela-na-kotyatahi-shchenkah (in Russian).

Pryima, O. B. (2013). Vzaiemovidnosyny v systemi "parazytk-haziain" za toksokarozu sobak [Relationships in the system "parasite-host" for toxocariasis of dogs] (Extended abstract of $\mathrm{PhD}$ dissertation). Natsionalnoy universytet bioresursiv i pryrodokorystuvannia Ukrainy, Kyiv, Ukraina (in Ukrainian).

Said V. S., Stybel V. V., Gytyj B. V., Pryima O. B., Sobolta A. G., Leskiv K. Y. (2020). Morphological parameters of dogs' blood under experimental toxocariasis. Colloquium-journal, 2020, №23 (75), 7 10. doi: 10.24411/2520-6990-2020-12135.

Said, W. S., Stybel, V. V., Gutyj, B. V., Pryima, O. B., \& Mazur, I. Y. (2020). Protein-synthesizing function and functional state of the liver of dogs at experimental toxocariasis. Scientific Messenger of Lviv National University of Veterinary Medicine and Biotechnologies. Series: Veterinary sciences, 22(98), 132-137. doi: $10.32718 /$ nvlvet9823.

Said, W. S., Stybel, V. V., Gytyj, B. V., Pryima, O. B., Sobolta, A. G., Leskiv, K. Y., \& Dytiuk, M. P. (2020). The state of the immune system of dogs in experimental toxocariasis. Ukrainian Journal of Veterinary and Agricultural Sciences, 3(3), 20-24. doi: 10.32718/ujvas3-3.04.

Said, W., Stybel, V., Gutyj, B., \& Prijma, O. (2020). Antioxidant protection system of dog organism at experimental toxocariasis. Bulletin of Poltava State Agrarian Academy, 3, 233-240. doi: 10.31210/visnyk2020.03.27.

Sheliakyn, Y. D., \& Cheskydova, L. V. (2016) Yzmenenye pokazatelei krovy korov pry eksperymentalnom lechenyy fastsyoleza [Changes in cow blood indicators during experimental treatment of fasciolesis]. Voronezh State Agrarian University Bulletin, 1, 45-50. doi: 10.17238/issn2071-2243.2016.1.45 (in Russian).

Soldatov, Y. S., \& Karmalyev, R. S. (2016). Jepizootologija i profilaktika gel'mintozov sobak [Epizootology and prevention of helminthiasis in dogs]. Theory and practice of control of parasitic diseases, 17(17), 447-449. URL: https://cyberleninka.ru/article/n/epizootologiya-iprofilaktika-gelmintozov-sobak (in Russian).

Volychev, A. N. (2003). Epyzootolohyia osnovnykh parazytozov plotoiadnykh $\mathrm{v}$ uslovyiakh horoda Moskvy [Epizootology of the main carnivorous parasites in the conditions of the city of Moscow]. Proceedings of the All-Russian Institute of Helminthology, 39, 55-64 (in Russian).

Ybyshov, D F, Ponosov, S. V, \& Nykolaeva, E. V. (2017). Osobennosty vlyianyia preparata Helmymaks na byokhymycheskye pokazately krovy sluzhebnykh sobak. [Features of the effect of the drug Helmimax on the biochemical parameters of the blood of service dogs]. Livestock and fodder production, 4(100), 142146 (in Russian). 